DOI https://doi.org/10.30525/978-9934-588-90-7-77

\title{
ОСОБЛИВОСТІ ВІДПРАЦЮВАННЯ НАВИЧОК ЧИТАННЯ З АНГЛОМОВНИМИ СТУДЕНТАМИ ПІД ЧАС ВИВЧЕННЯ УКРАЇНСЬКОЇ ЯК ІНОЗЕМНОЇ (ВІД ТЕХНІЧНОГО ДО ЗМІСТОВОГО АСПЕКТІВ)
}

\author{
Бойчук О. А. \\ кандидат філологічних наук,
}

доцент кафедри громадського здоров'я і гуманітарних дисциплін ДВНЗ «Ужггородський національний університет»

Гречин I. М.

асистент кафедри громадського здоров'я і гуманітарних дисииплін ДВНЗ «Ужгородський національний університет»

м. Ужгород, Україна

Читання $\epsilon$ одним із важливих видів комунікативно-пізнавальної діяльності, особливо на початкових етапах вивчення мови. Відповідно до сучасних методичних рекомендацій, «оволодіння звуками та інтонаційними моделями іноземної мови є необхідною передумовою розвитку вмінь спілкування у всіх видах мовленнєвої діяльності» [7, с. 90].

До проблем правильного і вчасного формування навичок читання та розуміння українськомовного тексту зверталися у свої дослідженнях Бойко Г. [1], Зозуля I. [4], Карловська Г [5], Карпенко С. [6], Станкевич Н. [8] та ін. Дослідники одностайно визнають читання найважливішим засобом навчання іноземної мови. Доводять, що уміння читати сприяє розширенню лексичного запасу, закріпленню граматичного матеріалу, міцному засвоєнню структурних форм мови; уможливлює подальше самостійне вивчення мови та позитивно впливає на вдосконалення мовленнєвих умінь. Утім чимало практичних аспектів цієї теми залишаються поза увагою дослідників. Тому тема статті $є$ актуальною та доцільною.

Мета повідомлення - проаналізувати підходи, спрямовані на формування навичок читання (від технічного аспекту до змістового), що були апробовані на медичному факультеті № 2 УжНУ під час роботи 3 англомовними іноземними студентами; звернути увагу на типи завдань, найбільш доречні на цьому етапі освоєння мови.

Відповідно до робочої програми, затвердженої на медичному факультеті № 2, вивчення фонетичних особливостей української мови відбувається на першому курсі впродовж 9 здвоєних занять, під час яких 284 
відбувається відпрацювання техніки та елементарних умінь читання, що $\epsilon$ характерною особливістю підготовчої стадії читання [3, с. 10-11]. Задля полегшення роботи на цьому етапі викладачами кафедри було укомплектовано навчально-методичний посібник «Вчимося читати українською» [2]. Відпрацювання техніки читання у цьому посібнику подається з урахуванням звукового, складового, порівняльного методів та методу цілих слів, кожен із яких має свої переваги та недоліки [3, с. 41], а їх комбінація видається найбільш оптимальною.

Літери та звуки в посібнику згруповано у розділи, в межах яких відбувається відпрацювання техніки читання. До кожного звуку подається пояснення щодо особливостей його вимови і звучання у порівнянні з англійською. Наприклад, звук [л], літера Л л - «The hard consonant similar to the English $\mathbf{I}$ in «health», but the tongue is shaped like a scoop: the front part is pressed to the upper teeth, the tip of the tongue is lowered to the bottom teeth (as for [т], [д], [н]); the middle part is lowered, the back part is raised» $[2$, c. 20$]$.

У кожному розділі-юніті представлені завдання на відпрацювання вимови нових звуків, починаючи від складів (але не більше одного-двох, оскільки склади не мають інформативної цінності, тому студенти швидко втрачають інтерес) до слів, речень.

Подача нової інформації відбувається за принципом нашарування. Так, у кожному юніті студенти відпрацьовують читання слів, до складу яких входять нові літери та вивчені у попередніх розділах (тобто відбувається активна лексична робота, i, як наслідок, після завершення цього курсу студенти опановують більше 250 слів, які вкінці посібника подано у формі алфавітного і тематичного словників) [2, с. 56-77]. Вивчення нових слів закріплюється читанням речень. При цьому викладач постійно наголошує на інформативності останніх, а не тільки їх формальному озвученні. Звертається увага і на інтонування речень.

Паралельно 3 читанням відбувається відпрацювання навичок письма. Цьому допомагають завдання на кшталт: запишіть слова українською [l'íkar], [kól'ir], [poned'ílok] тощо. 3 цією ж метою проводяться і мінідиктанти.

Звичайно, більшість завдань початкового етапу мають некомунікативний характер, тому, аби студенти не втрачали інтерес, доречно до вправ на вимову, лексичних або граматичних завдань додавати ігровий елемент. Наприклад: 1) Викладач називає літеру, а студенти озвучують слова, де ця літера зустрічається («Хто більше?»); 2) Викладач роздає картки, де записані перші та останні літери слів із пропусками на відповідну кількість літер, які потрібно дописати. Виграє той, хто зробить більше і швидше («Вгадай слово») [9, с. 206] 3) Утворити слова із розданих студентам частин слова («Яке слово?») тощо. 
Особливості інтонування речень в українській мові можна також відпрацьовувати в ігровій формі. Наприклад, роздати студентам картки зі знаком питання, знаком оклику та крапкою. Викладач читає речення 3 певною інтонацією, а студенти визначають $\dddot{11}$, демонструючи відповідний пунктуаційний знак. Це ж завдання можна відпрацьовувати між групами / парами студентів.

Працюючи з вимовою, студенти також вивчають готові фрази, які $€$ невід'ємними у формуванні комунікативних навичок, поступово переходять від читання окремих речень до мікродіалогів, а відтак і до роботи з текстами. Тобто відбувається перехід до стадії зрілого читання [3, с. 10-11], головна мета якого - здобуття інформації з тексту. Перші тексти - прості, зорієнтовані на грунтовне, вивчаюче читання: відпрацьовується лексика, певні граматичні конструкції або категорії, інтонування речень, післятекстові запитання та відповіді на них [2, c. 43-55].

Відтак, на вищому рівні опанування мови, тексти стають більш інформативними. Опановується читання з охопленням основного змісту та 3 метою пошуку інформації. Тобто, відбувається комунікативне читання. Такі тексти містять дотекстові, текстові та післятекстові завдання, в результаті опрацювання яких студентам пропонується висловитися з приводу прочитаного.

Добір якісного тексту для читання - це важка і відповідальна робота. Важливо, щоб тексти були, щонайперше, цікавими для читання. Адже, як показує досвід, важчі тексти для читання, але які викликали зацікавлення у студентів, були інформативними, пізнавальними, демонструють більш позитивну динаміку у розвитку комунікативних здібностей, ніж легкі та малоінформативні. Утім, робота 3 текстами - це тема окремого дослідження.

Отож, читання відіграє надзвичайно важливу роль у формуванні комунікативних здібностей студентів, а правильне і грамотне налагодження процесу навчання читання, а відтак відпрацювання його навичок (із продуманим способом подачі матеріалу, добором завдань відповідного рівня, активним заохоченням студентів до процесу читання) стануть запорукою успіху у формуванні мовленнєво-комунікативної компетентності.

\section{Література:}

1. Бойко Г.І. Удосконалення навиків читання студентів-іноземців на заняттях 3 української мови як іноземної. Парадигма пізнання: гуманітарні питання. Київ, 2016. ХІІІ. Вип. № 2 (13). С. 125-136. 
2. Вчимося читати українською. Learn to read Ukrainian: навчальнометодичний посібник $з$ дисципліни «Українська мова» для англомовних іноземних студентів медичного факультету № 2 за напрямом підготовки 7.12010001 «Лікувальна справа» / уклад. О.А. Бойчук. Ужгород: ДВНЗ «УжНУ», 2017. 78 с.

3. Єременко Т.Є., Трубіцина О.М., Лук'янченко I.О., Юмрукуз А.А. Навчання читання англійською мовою студентів мовних факультетів. Навчальний посібник з курсу методики викладання іноземних мов у закладах вищої освіти. Одеса, 2018. 201 с.

4. Зозуля I.С. Навчання читання іноземних студентів україномовних текстів (початковий етап). Закарпатські філологічні студіï. 2018. Вип. 5. T. 1. C. 20-25. URL: http://ir.lib.vntu.edu.ua//handle/123456789/23389 (дата звернення: 20.10.2020); Зозуля І. С. Текст як засіб контролю в навчанні українській мові як іноземній. Молодий вчений. Спецвипуск. 2019. № 6.1 (70.1). C. $21-26$

5. Карловська Г. В. Навчання професійного читання у вищих навчальних закладах України. URL: http://eprints.cdu.edu.ua/1441/1/14242-45.pdf (дата звернення: 20.10.2020)

6. Карпенко С.Д. Формування навички читання та розуміння україномовного тексту у студентів-іноземців. Молодий вчений. Спецвипуск. 2019. № 6.1 (70.1). С. 33-37

7. Методика навчання іноземних мов у загальноосвітніх навчальних закладах: підручник / Л.С. Панова, І.Ф. Андрійко, С.В. Тезікова та ін. Київ: ВЦ «Академія», 2010. 328 с.

8. Станкевич Н.I. Види читання в курсі української мови як іноземної. Теорія і практика викладання української мови як іноземної. 2013. Вип. 8. С. 186-193.

9. Тарнопольський О.Б. Методика викладання іноземних мов та їх аспектів у вищій школі: підручник. Дніпро: Університет імені Альфреда Нобеля, 2019. 256 c. URL: https://ir.duan.edu.ua/bitstream/123456789/ 1642/ 1/монограф_Тарнапольский.pdf\%20(дата\%20звернення:\%2020.10.2020) 